\title{
Financial Inclusion and Income Inequality in Mexican Municipalities
}

\author{
José Salazar-Cantú1, Juvencio Jaramillo-Garza², Bethzaira Álvarez-De la Rosa ${ }^{3}$ \\ ${ }^{1}$ Economics Department, Tecnologico de Monterrey, Monterrey, México \\ ${ }^{2}$ Facultad de Ingeniería Mecánica y Eléctrica (FIME), Universidad Autonoma de Nuevo Leon, San Nicolás de los \\ Garza, México \\ ${ }^{3}$ Universidad Juarez Autonoma de Tabasco, Villahermosa, México \\ Email: jsalazar@itesm.mx,jjgjaramillo@yahoo.com,bethzaira.alvarez@outlook.com
}

Received 6 November 2015; accepted 5 December 2015; published 10 December 2015

Copyright (C) 2015 by authors and Scientific Research Publishing Inc.

This work is licensed under the Creative Commons Attribution International License (CC BY). http://creativecommons.org/licenses/by/4.0/

(c) (i) Open Access

\begin{abstract}
The Greenwood and Jovanovic (1990) [1], hypothesis, about the influence of the financial inclusion on the inequality in the income distribution, is tested for the Mexican municipalities. The results of the econometric estimation, confirm the theoretical expectative, indicating that a higher financial inclusion would lead initially to a greater income inequality within the Mexican municipalities, so that later on as the inclusion continues growing that inequality reduces. These findings, obtained through the use of regional information for a same country, are the first of its kind on available literature; and suggest the need for more regional approaches, rather than national, in the public policy on the complex social problem of income inequality.
\end{abstract}

\section{Keywords}

Income Inequality, Financial Inclusion, Social Cohesion, Mexican Municipalities

\section{Introduction}

Reference [2] states that as capitalism leads to wealth growth and accumulation, it has also been a polarizing influence over income distribution, which forces governmental entities to deal with the problem. The author approaches the known phenomenon initially exposed by [3], on the expected correlation between income growth and inequality in its distribution, which would be given in any society through its economic development stages.

Reference [1] widens Kuznets model and formally proves the non-linear relationship, also shaped as an inverted "U", that is expected between a country's financial development and its income distribution coefficient. This study proves Greenwood and Jovanovic’s thesis applied on Mexico’s 2456 municipalities. 


\section{According to [4]:}

Income inequality is a major concern in development and welfare economics, especially as it relates to developing countries. Such inequality can be interpreted as a sign of injustice, insider privilege, unequal opportunity and social instability. In developing countries, income inequality is observed to be destructive and problematic to society and the economy. (p. 552)

Reference [5] mentions: "To talk about inequality is to touch the deepest problem in society at the same time as the hardest challenge for those who consider ourselves Christians.” (p. 28). This last expression took a higher relevance in Mexico's case, where 82.7 per cent of the population in 2010 reported being Catholic (National Institute of Statistics and Geography, INEGI as its initials in Spanish, 2010) [6].

Even if a debate is still going on whether inequality is really a problem at all, [7] affirms: "What we do know is that the benefits of additional income is undoubtedly lower for the rich, and that constitutes the main link between inequality and average happiness.” (p. 61). For Mexico's particular case, [8] have proven the direct relationship between income inequality and crime.

Inequality is a historic feature of Mexican society, as [9] mention that it existed before Columbus arrived to the American continent. According to [10], when analyzing the called stabilizing development period (19501974), it demonstrated how the economic model instated in that era meant a higher concentration of income, making Mexico one of the worst countries in the world regarding income distribution. According to [11] its level of inequality in income distribution, measured using the Gini coefficient, is located in the 14th percentile on a group of 149 countries. This information locates only 21 on this particular group of countries, with an inequality coefficient higher than Mexico. If the comparison is made with disposable income data and using the most recent information published by [12], which analyses information for 171 countries, 31 of which have a Gini coefficient higher than Mexico's, therefore situating it on the 18th percentile, that is, the most unequal quintile in the world.

According to [1], the stage of financial development in which a society is immersed influences the level of inequality on income distribution of such.

A country or region's financial development can be observed in many ways, one is credit depth. For Mexico's case, [11] evidences a significant backwardness on the lending of credit as a proportion of the gross domestic product. 2013 data indicate that in Mexico such rate reached a 22 per cent, considerably lower than the world's average of 88 per cent or 86 per cent that corresponds to the average on the middle income countries, exactly half than that of the rest of Latin America and the Caribbean, which is at a 44 per cent, and even lower than the average of low-income economies, which was 27 per cent that year.

Mexico's conditions for financial development on a regional level can be measured by the uptake balances in local and foreign currency made by commercial banks. 2010 data obtained from the Municipal and Federal System of Data Bases (SIMBAD as its initials in Spanish) by INEGI and this study's calculations, show that 69.6 per cent of monetary save uptake on a national level came from the Distrito Federal state, followed by a 13.1 per cent from Nuevo Leon state and 2.9 per cent from Jalisco state. 27 of the 32 federal states received individually less than 1 per cent of the nation's total save uptake.

Based on the data gathered by the National Survey for Financial Inclusion in 2012 by INEGI, [13] study the determinants of inclusion in Mexico, and in their conclusions they affirm:

Even though 73 per cent of the municipalities in Mexico (with a 97 per cent coverage of the adult population) have at least one access point to the financial system, this rate is lower than that of other Latin-American nations like Brazil, Chile, and even Peru. The current offer reached by regulatory changes and the public policy for financial inclusion has only reached 38 per cent of the adults between 18 and 70 years of age that have at least some form of savings or credit with formal financial institutions (p. 21).

Mexico's case, that shows high levels of inequality in its distribution of income, on a par with a low rate in key indicators for its financial development, is an interesting study case. The high level of inequality and low financial inclusion that it lives is similar to other Latin-American countries.

As [14] states, next to Brazil and Peru, Mexico is one of the region's nations that has the most information available regarding financial inclusion, which is indispensable to analyze its causes and effects.

Income distribution is an important concern for fiscal policy in any country, and Mexico is not the exception. At the beginning of 2015, the Secretariat of Treasury and Public Credit (SHCP, as its initials in Spanish), revealed a study [15] on the impact of the tax burden and public spending distribution, by population deciles, on the national level of income distribution inequality. According to the document and the present study's calculations, in 2012 social public expenditure in Mexico was of 1,387,547.2 million of pesos (104,014 million of US 
dollars) and represented the 23.9 per cent of the total public expenditure, as well as 9.2 per cent of the gross domestic product. The analysis by SHCP concludes that the net impact of taxation and expenditure execution between deciles would have meant a reduction of inequality on a national level. It also demonstrated that some of the social programs that are more focused on vulnerable or marginal sectors produce an isolated progressive effect that also reduces inequality. Among these programs are Scholarship Opportunities, Opportunities, Food Support, Public Social Security and ProCampo (Pro-Rural Sector).

The study calculates the impact on a national level, but doesn't mention local or regional effects produced on a municipal level, where the presence of social programs would supposedly be a differential, depending on the intensity of poverty and inequality on each municipality.

Reference [16] state that investigation on the effect of financial inclusion has been left out, at the same time, [13] explain the need for the study of financial inclusion on a municipal level in Mexico.

Through statistical tests, the present research contributes to the study of the phenomenon of income distribution inequality on a municipal level in Mexico. The consideration of determinants of financial inclusion on this level is still a novelty on the empirical study of inequality for Mexico's case. It is considered that the results of the analysis may be of interest to the Mexican government, which in the National Development Plan 2013-2018 (PND) formulated by president [17] in the section "Inclusive Mexico", establishes in objective 2.2: "Transit towards an equal and inclusive society" (p. 116), also, in the "Prosperous Mexico" section, objective 4.2: "Democratize the access to the financing of projects with growth potential.” (p. 132).

The intention of Mexican public policy to democratize the financial system is part of the legacy of the 2007-2012 National Development Plan, which led to the creation of the National Council of Financial Inclusion, with the goal of designing and executing a national policy of financial inclusion [18].

Financial Inclusion is also of interest to the financial sector institutions, for which a developing country that is socially stable promises a better future regarding saving and using credit, as well as other services such sector offers, like insurances, bail fees, the payment of public services, and others, responding also to the increase of new information and communication technologies, that according to the 14/2011 bill published by [19], are now formal and official media for accessing the financial system. The changes the bill proposes intentions are:

1) To impulse that a larger sector of the population has access to banking services; 2 ) That these promote the use of new media, so the citizens can access resources provided by the institutions; and 3) That they facilitate the citizens to use the resources by means those are efficient and expedite (p. 1).

Devices such as mobile phones and computer can not only be the most used media for accessing financial inclusion, but also social inclusion. For Mexico's case, the estimations of [20], calculate that there are at least 22 million of mobile phone users that have not yet linked their phone to a banking account. This is important because it speaks about financial inclusion's potential growth and its possible economic and social effects.

The present investigation makes three contributions to the study of the effects of financial inclusion on income distribution. The first one consists in confirming that the level of financial inclusion on Mexico's municipalities is a statistically significant determinant of income distribution inequality in them, as proposed by [1] theory. This demonstration used regional information for a same country and is the first of its kind on available literature, and suggest the need for more regional approaches, rather than national, in the political directions of this field. The second contribution is given in terms of employment of two inclusion measures, one of measures the using of financial system and the other, almost never used in available literature, measures the access to the financial system, which strengthens empiric results. Finally, the third contribution comes from the classification of the 2456 municipalities that integrate the Mexican territory, according to their level of financial inclusion and income distribution, which facilitates the implementation of financial inclusion efforts.

Statistical tests of the phenomenon were executed based on available official information of about 80 to 85 per cent of Mexican municipalities, and it would be worth it to re-evaluate the results once 100 per cent of information is reached.

The rest of the document is divided in five parts: theoretical framework, revision of literature, methodology and data, and results and conclusions.

\section{Theoretical Framework}

Reference [1] model comes from the expected correlation between income level and its distribution inequality, discovered by [3] and adds to this correlation the effect of financial development on economic growth and in- 
equality level.

The study matter also considers the concept of financial development, which refers to the level in which the institutional structure that intermediates savings and credit in a society acts efficiently to promote growth and is accessible to different groups of economic agents that compose said society. The present study uses the concept of financial inclusion as a way of understanding financial development.

The National Council of Financial Inclusion (CONAIF, as its initials in Spanish) [21] defines the financial inclusion concept (2015): "The access and use of formal financial services under an appropriated regulation that guarantees the consumer schemes of protection and promotes financial education to better the financial capabilities of all population's segments."

Reference [1] contemplate the evolution of an economical system in three stages: Infant, intermediate and mature. In the first one, markets aren't present or are so in a diluted way and economic growth is slow. In the intermediate stage, income reaches a level that allows increasing savings. This leads to the endogenous rise of some financial intermediaries that give preferential services to the most economically developed social classes, a process that increases the gap between the poor and rich and inequality in the distribution of income.

As low and middle classes integrate to economic activity and demand for financial services, these extend to such sectors, which allows the system to go into its mature stage, in which financial intermediation structures have been developed, income distribution tends to a lower inequality and stabilizes, the savings rate drops and economic growth rates converge to a higher level prior to the infant or initial stage.

According to [1] model, the initial impulse that ignites the system's evolution is economic growth, which combined with the increase in expected profitability of investments, leads to the endogenous emerging of organizational capital and financial institutions. The first one appears in the form of public and/or private institutions that through mutual contribution shape information make strategic analysis and offer order elements, funded mutually and whose extension grows parallel to the savings and investment dimensions. Figure 1 shows some of the elements regarding the relation between economic and financial growth in a society.

From [1] model, as the financial system develops and its service encompasses the different income groups, it will have a positive influence towards leading society to a stable and more equalitarian income distribution. Financial institutions are also responsible for acting in favor of such development, but other institutional factors that derive from the legal system and cultural paradigm in which the society expresses itself also come in play.

The influence of financial development on income distribution inequality has also been studied by [22], whose hypothesis differs from that of [1].

According to [22] model has as a result the hypothesis of inequality, where the financial system's imperfections lead to a higher divergence between the income of different socioeconomic groups. The authors explain why some countries that start with similar social structures and economic resources then move into different stages, where some maintain a small business owners, artisans and interns occupational structure, while others grow into nations of businessmen that employ workers in large factories, some progress while other stale.

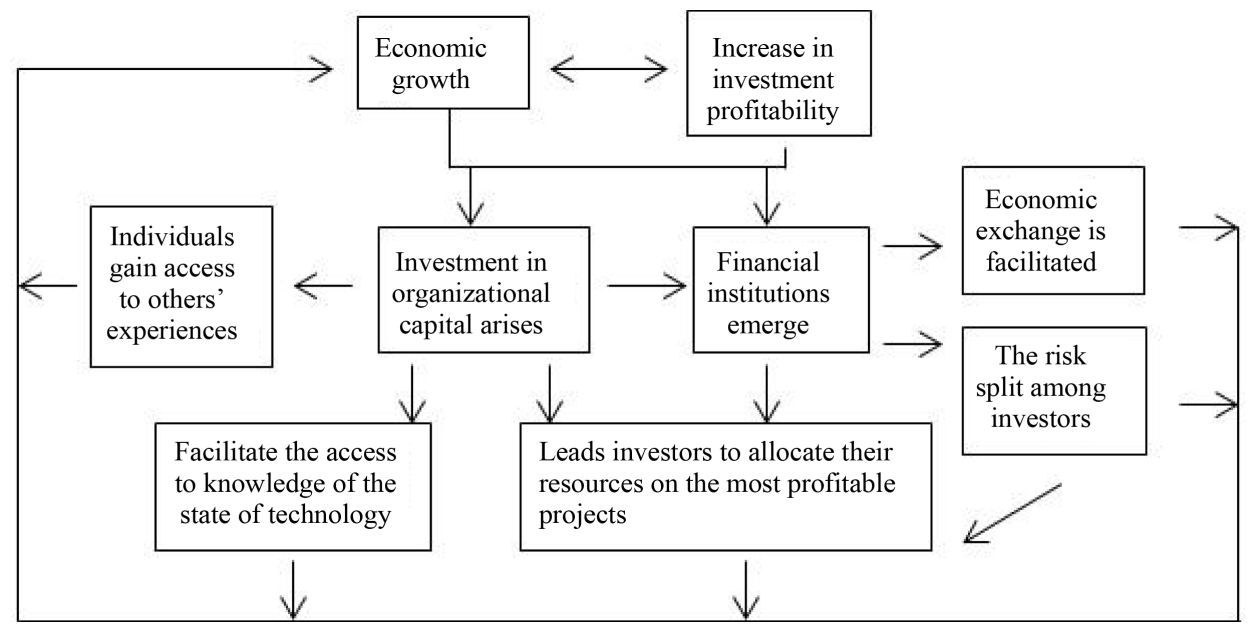

Figure 1. Economic growth and financial development. Source: Made based in Greenwoody Jovanovic (1990). 
For [22] the dynamics of occupational structure affect income distribution, which determines some of the macroeconomic aggregates, as savings and investment, and aggregate supply and demand. These authors state that the importance of financial development lies in the fact that its imperfections determine employment structure. Occupations that demand for high investments will be out of reach for poor people, who will then work for wealthier employers. As long as the financial system doesn't give access opportunities to the lower sectors and the occupational structure exacerbates the duality of employer and employee, inequality will continue to grow.

Like [1] [23] conceives the possibility of an inverted U relation between financial inclusion and distribution of income, but by different means. In his general model, Matsuyama shows how the stable equilibrium state of an economy implies an unequal distribution of wealth. Under the assumptions that projects that generate high profit rates require a minimum level of investment, and that given the default chance, whoever wants to invest in these will have to ask for a loan, the author anticipates that the relatively rich families will have access to credit and investment, while poor families will become their lenders, charging rates that will be lower than the investment project ones. The last event will lead only to the rich becoming richer and the poor relatively poorer, increasing inequality in an endogenous way. Inequality may not be perpetuated, but reduced in those cases that a high credit demand by the rich increases the interest rates paid to the poor's savings, which would then see their wealth grow. This situation would lead to an inverted U correlation, as proposed by [1] but that responds mainly to a condition of increase in the passive rates and not as much to the development of a financial market that reaches the lower sectors of the population.

The present study considers [1] model as a base, which allows to conceive on a cross-section the differential situation of financial development that a group of differentiated economic societies face, that, in this case, will be constituted by Mexico's municipalities, which, as [24] state form a mosaic, whose level of population diversity affects its level of economic growth. We consider that while [23] model predicts a similar inverted U behavior, the reason of such is less probable in Mexico's case, where for decades, while the interest rates applied to credits has been high, the one paid to the savers has been low, even negative in real terms.

Two null hypotheses were obtained from the theoretical framework: 1) There is no relation between the level of financial inclusion and income distribution inequality in the municipalities of Mexico, and 2) The relation between the level of financial inclusion and income distribution inequality is a lineal one.

Next we present the revision of the empirical work so far done on the study phenomenon.

\section{Literature Review}

The subject of financial inclusion, causes and effects, has received attention mainly since the $90 \mathrm{~s}$ and on. According to [16] point out that the study of the effect of financial inclusion on income distribution has not been addressed enough.

Financial inclusion is on the political agenda of all central banks of a wide group of countries, this is backed by the creation of the Alliance for Financial Inclusion (AFI) in 2009, which integrates monetary policy makers from developed and developing nations. Efforts in this subject matter have been remarkable in some developing nations like Brazil, China, Colombia, India, Peru, and, more recently, Mexico. The studies referring to its causes and effects have used data bases for groups of countries and compared them to each other [4] [16] [25]-[31].

There is also a group of documents that refer to the study of individual countries, among them: [32] study the Peruvian model, [13] show the state of financial inclusion in Mexico and its determinants, [33] estimate the impact of banking correspondents over financial inclusion in Mexico, [20] study the advances of mobile banking in Mexico, [34] estimate the influence of financial inclusion in the efficiency of monetary policy in Nigeria, and [35] compare the scope of financial inclusion in UK and USA.

There is little investigation on the phenomenon of inclusion on a regional level towards the insides of a country. In this study line, [36] work correlates financial inclusion with literacy for the 29 Indian states. For Mexico's case, [37] study the city of Autlan, where they evidence the latent demand for financial services amongst the lower income sectors; and [38] for the city of Monterrey, who propose a model of inclusion originating from micro family businesses. Continuing with regional studies, [39] analyze the case of the Indian state of Jammu and Kashmir, and show how the financial development in India has helped economic growth, but hasn't been inclusive and presents differential effects among its regions.

References [13] [30] [38] [40], express the need to study the inclusion phenomenon on a regional level. The present study is one of the first to show the effect of financial inclusion on income distribution, based on infor- 
mation on a municipal level for a country, in this case, Mexico.

The recent emergence of interest on the phenomenon of financial inclusion and the great expectations it has aroused is notable, since it is conceived as a form of economic and social inclusion. While the presence of a dominant theory is still not perceived, proposals and base models employed in the bulk of literature are circumscribed in the first place to [1] work, followed by [22]. This study also takes as a point of central theoretical [1] model.

The investigation methodologies used by different authors are mostly of a quantitative approach, and can be divided in two general groups; descriptive [13] [20] [28] [32] [36] [37] [39] [40]; and causal, which make use of statistic and econometric methods: [4] [16] [25]-[31] [33] [34] [38]. The present study uses the Ordinary Least Squares (OLS) econometric regression method, based on municipal 2010 year data.

The way in which different authors measure financial inclusion refers generally to the use of collection and/or loan by the financial system. To measure income distribution inequality, all use Gini coefficient.

Most part of the reviewed literature proves the effects of financial inclusion over different macroeconomic variables. For the particular case of the effects on income distribution, [16] using data for a group of countries, find a negative relation between inclusion and inequality. When [25] comparing developing countries versus transitional countries, find that in the first there is no relation between financial inclusion and income inequality, while in the second ones, there is the inverted U relationship. Using data from 35 developing countries [4] confirm the existence of an inverted $U$ relationship before a certain level of financial development, and after it such relation is no longer sustained. Reference [29] makes use of information from 160 countries and confirms the relation between a higher financial inclusion and a lower inequality level, but not with less poverty. Finally, when studying a group of 83 countries, [30] found robust results of reduction of inequality after the increase of financial depth and less robust over the inverted U behavior. Even if results are diverse, they all tend to evidence the frequent influence of financial inclusion on income distribution.

In the present study's review of literature no statistical work was found that proved neither the phenomenon under analysis for the regions of a same country, nor for Mexico's case, whether it is seen as a whole, or according to any of its geographical divisions. We consider that as it is important to prove the effects between countries, it is also indispensable to study the phenomenon on a micro-level, making comparisons between regions, mostly on cases where differences among population groups are strongly developed. Mexican municipalities' case is representative of this condition, some authors lead to consider this, [41] makes the statement: "If there is a country that is plural and diverse, unpredictable and complex, that is Mexico” (p. 5). Reference [42] prove that monetary policies in Mexico have had a differential effect over Mexico's diverse geographic regions. Mexico's case is also representative of countries with high levels of income distribution inequality, many of them located in the southern hemisphere and especially in Latin America, as [43] evidences, is the world's most unequal region.

A factor that usually influences income distribution is public expenditure. Reference [44] indicate that the budget allocation for public municipal social expenditure doesn't follow a random path, but adopts rational elements, which leads to think that available theory, also based on rationality, may as well explain Mexico's case and other similar ones. Next we present the methodology, and describe data and its sources.

\section{Methodology and Data}

The OLS regression method will be used in order to test the hypotheses. The function that will be estimated is shaped as the following equation, initially used by [30] and also applied by [25]. The specification differences between the mentioned studies and the present one are located in the financial inclusion index construction, and the aggregation level of the variable group that conforms the $V$ vector, which in the present study corresponds to the regional level, and in the others, to comparison between countries. Another difference comes in terms of using alternatively 2 variables as a proxy for the income distribution level, first Gini, which is the variable used by all authors, and the income ratio (ri), a variable that represents a novelty in the study of the phenomenon and that would help to increase confidence in the obtained results.

$$
\operatorname{Gini}_{j}=\alpha+\beta_{1} \text { iia }_{j}+\beta_{2} \text { iia }_{j}^{2}+\beta_{3} V_{j}+\varepsilon
$$

where:

Gini $i_{j}$ : Income inequality coefficient for each $j$ municipality;

$r i_{j}$ : income ratio from the extreme poverty sector to the not-poor nor-vulnerable sector for each $j$ municipality, 
(Used alternately instead of Gini);

$\mathrm{iia}_{j}$, iiuj: financial inclusion access (iia) and usage (iiu) index for each $j$ municipality;

$V_{j}$ : Socioeconomic control variables vector for each $j$ municipality;

$\beta_{1}, \beta_{2}, \beta_{3}$ : relation coefficients between the explicative and the dependent variables.

$j: 1,2,3, \cdots, 2456$.

$\varepsilon$ : Error term.

According to [1] theoretic model, it would be expected that: $\beta_{1}>0$ and $\beta_{2}<0$ and inverse when using income ratio as dependent. The model's specification also allows to prove the inequality hypothesis by [22] according to which $\beta_{1}>0$ y $\beta_{1}=0$, this last result may also reflect Matsuyama's (2000) general case thesis.

The socioeconomic variables $V_{j}$ vector includes concepts on a municipal level for: householders average years of education, a per capita income proxy variable, the ethno-linguistic fractionalization rate, and the per capita public expenditure.

According to the literature review and [3], income has an inverted U relation with the level of income distribution inequality, in this case, the level of educational development in Mexico would locate most of the municipalities on the ascending part of the inverted $U$, since the national census data [6], according with the average of schooling years of the householders, 66.1 per cent of the municipalities doesn't reach complete elementary school, and 95.2 per cent doesn't reach complete junior high. Following [35] it would be expected that a higher rate of population diversity would also lead to a higher Gini; finally, being that reducing inequality a public objective and following [30], higher public expenditure per capita would lead to the expectancy of a lower Gini.

From the literature review it can be stated that there is no standard approach for defining nor measuring financial inclusion, mostly, data constructed from references to the access or usage of the financial system are used. In the present study, the financial inclusion rate adopted two shapes, both within CONAIF's definition, mentioned in the theoretical framework section, which contemplates both access to the financial system (iia) as well as usage (iiu). The first is an additive index that sums the averages of: bank branches, ATMs and banking correspondents per each 10,000 inhabitants. The latter is an additive index that sums the contracts of: checking and savings accounts, payrolls, term deposits, debit and credit cards and the number of mortgage and group loans per each 10,000 inhabitants.

These approaches to construct the financial inclusion variable aren't bulletproof. When speaking about financial access, it would have to be mentioned that bank branches aren't as homogenized as the ATMs and bank correspondents could be. When speaking about the use of the financial system, a same person can own several accounts, which leads to an inclusion overestimation. As far as it could be investigated in the present study's theoretical framework, it was not possible to access personal/individual data, so the method (in a simplistic way) assumes that a single account corresponds to a single person. Implicitly, both rates give the same importance to each of the concepts they include, which is also an oversimplification that can be fixed in following studies, where the importance of each is weighted. Meanwhile, these rates can be seen as indicators of access points' presence and their apparent demand respectively.

Table 1 summarizes the abbreviations, description and sources for the variables that intervene in the testing of both of the present study's null hypotheses.

The next section presents the results obtained from the statistical analysis, first contemplates descriptive statistics and then the regression analysis.

\section{Results}

Table 2 summarizes the descriptive statistics. The average for the Gini coefficient among Mexican municipalities is of 0.412 with a 0.039 standard deviation. The income ratio showed a difference of almost 8 times between the most poverty stricken sector and the non-poor nor vulnerable. The medians for inclusion access and usage rates allows to observe that at least half of Mexican municipalities have low financial inclusion levels, in the inclusion access case, the median is of 1.5 access points, while in the inclusion usage case the median was 570 accounts, both per every 10,000 inhabitants. The latter statistic would imply that in average, 9430 of every 10,000 Mexican inhabitants didn't make use of the formal financial system by 2010. If it is also considered that individuals may own more than one account, the 570 that are mentioned might be distributed amongst less than 570 individuals, and the inclusion level would be even lower.

The householders' average years of education didn't reach the end of elementary school studies, and income, 
Table 1. Variables, description and their sources.

\begin{tabular}{|c|c|c|}
\hline \multicolumn{3}{|r|}{ Variables } \\
\hline Abbreviations & Description & Source \\
\hline Gini & $\begin{array}{l}\text { Gini inequality coefficient, takes } \\
\text { values ranging from } 0 \text { to } 1 \text {, where } 0 \text { is } \\
\text { equalitarian income distribution and } 1 \\
\text { means a total concentration. }\end{array}$ & $\begin{array}{l}\text { National Council for the Evaluation of the Social } \\
\text { Development Policy (CONEVAL, as its } \\
\text { initials in Spanish). } \\
\text { http://www.coneval.gob.mx/Medicion/Paginas/Cohesion_Social.aspx }\end{array}$ \\
\hline ri & $\begin{array}{l}\text { Income ratio. Current income of the } \\
\text { extreme poverty households group as } \\
\text { a proportion of the current income of } \\
\text { the households group non-poor and } \\
\text { non-vulnerable. }\end{array}$ & $\begin{array}{l}\text { National Council for the Evaluation of the Social } \\
\text { Development Policy. } \\
\text { http://www.coneval.gob.mx/Medicion/Paginas/Cohesion_Social.aspx }\end{array}$ \\
\hline iia & $\begin{array}{l}\text { Inclusion access rate. Sums the } \\
\text { average of: bank branches, banking } \\
\text { correspondents and ATMs per } \\
\text { 10,000 inhabitants. }\end{array}$ & $\begin{array}{c}\text { National Banking and Securities Commission. } \\
\text { http://portafoliodeinformacion.cnbv.gob.mx/estudios/Paginas/default.aspx }\end{array}$ \\
\hline iiu & $\begin{array}{l}\text { Inclusion usage rate. Sums: checking } \\
\text { and savings accounts, payrolls, term } \\
\text { deposits, debit and credit cards, term } \\
\text { deposit, and number of mortgage and } \\
\text { group loans, per 10,000 inhabitants. }\end{array}$ & $\begin{array}{l}\text { National Banking and Securities Commission. } \\
\underline{\text { http://portafoliodeinformacion.cnbv.gob.mx/estudios/Paginas/default.aspx }}\end{array}$ \\
\hline edu & $\begin{array}{l}\text { Average householders years of } \\
\text { education groups at a municipal level. }\end{array}$ & $\begin{array}{c}\text { National Banking and Securities Commission. } \\
\text { http://portafoliodeinformacion.cnbv.gob.mx/estudios/Paginas/default.aspx }\end{array}$ \\
\hline pibpr10 & $\begin{array}{l}2010 \text { municipal income per capita } \\
\text { proxy. An estimate made following } \\
\text { [49] which parts from the state GDP } \\
\text { and is charged through employment. }\end{array}$ & $\begin{array}{l}\text { Data base built by: [49]. Data is expressed in thousands of constant pesos } \\
\text { for } 2003 .\end{array}$ \\
\hline idel & $\begin{array}{l}\text { Ethno-linguistic fractionalization } \\
\text { rate, seen as a rate for population } \\
\text { diversity. The percentage of } \\
\text { municipal population speaks } \\
\text { one or more indigenous } \\
\text { languages or dialects. }\end{array}$ & $\begin{array}{l}\text { Reference [24]. (Open access data base: } \quad \text { https://drive.google.com, file: } \\
\text { base de datos sem (1), user: sem.mex.ad13, pwd: diversidad). }\end{array}$ \\
\hline gpub & $\begin{array}{l}2010 \text { municipal public expenditure } \\
\text { per capita, in current pesos. }\end{array}$ & $\begin{array}{c}\text { National Institute for the Federalism and Municipal Development. } \\
\text { http://www.snim.rami.gob.mx/ }\end{array}$ \\
\hline
\end{tabular}

Source: Made by the authors.

measured by the GDP per capita in 2003 Mexican current pesos, locate Mexico in the international panorama as a middle-income country. The diversity median, measured through the ethno-linguistic fractionalization rate, reveals that half of Mexican municipalities had a homogenous population. Lastly, the median for per capita annual public expenditure, measured in 2010 current pesos, is located at 3280 pesos (250 USA dollars in 2010), which addresses very limited expenditure levels, since, disregarding the municipality's size, the needs for infrastructure, security, law enforcement, public services and current expenditure in general by municipal administrations would regularly press upon such amount.

The lower part of Table 2 presents the correlation coefficients between the studied variables. There is a high correlation between Gini coefficient and income ratio, and between education and the usage index of financial inclusion. Low correlation levels between the explicative variables are one of the elements that lead to trust on the OLS method to estimate the regression equation, since the potential problem of multicollinearity is reduced.

In the estimation of the regression equation, the Gini coefficient was used as a dependent variable; it was also tested with the income ratio (ri) variable. For each of the two the relation coefficients with the financial inclusion variable were also estimated. The last variable, as it was explained in the methodology section, was structured both as an inclusion access index (iia, iia $^{2}$ ), and as an inclusion usage index (iiu, iiu ${ }^{2}$ ) this following CONAIF's definition, which contemplates both parts. It was also tested using two other paths for measuring inclusion: Credit/GDP and Deposits/GDP, both representatives of the formal financial system's use, but statistically 
Table 2. Descriptive statistics.

\begin{tabular}{|c|c|c|c|c|c|c|c|c|}
\hline \multirow[b]{2}{*}{ Concept } & \multicolumn{3}{|c|}{ Variables } & \multirow[b]{2}{*}{$\begin{array}{l}\text { Financial } \\
\text { usage } \\
\text { index } \\
\text { (iiu) }\end{array}$} & \multirow[b]{2}{*}{$\begin{array}{l}\text { Average } \\
\text { years of } \\
\text { education } \\
\text { (edu) }\end{array}$} & \multirow[b]{2}{*}{$\begin{array}{c}2010 \\
\text { income, } \\
\text { thousands } \\
\text { of } 2003 \\
\text { (pibpr10) }\end{array}$} & \multirow[b]{2}{*}{$\begin{array}{l}\text { Population } \\
\text { diversity } \\
\text { (idel) }\end{array}$} & \multirow[b]{2}{*}{$\begin{array}{l}2010 \text { current } \\
\text { pesos, per } \\
\text { capita public } \\
\text { expenditure } \\
\text { (gpubp) }\end{array}$} \\
\hline & Gini & $\begin{array}{l}\text { Income } \\
\text { ratio (ri) }\end{array}$ & $\begin{array}{l}\text { Financial } \\
\text { access } \\
\text { index (iia) }\end{array}$ & & & & & \\
\hline Average & 0.4120 & 0.1283 & 3.1421 & 5758.93 & 5.5613 & 79.3535 & 0.1181 & 3961.7 \\
\hline Median & 0.4083 & 0.1300 & 1.4996 & 570.22 & 5.2941 & 71.9150 & 0.0276 & 3280.0 \\
\hline Maximum & 0.5908 & 0.2800 & 52.8963 & 77175.25 & 13.8971 & 1364.2100 & 0.5000 & $33,562.7$ \\
\hline Minimum & 0.2857 & 0.0400 & 0.0000 & 0.0000 & 1.3302 & 9.6800 & 0.0000 & 744.3 \\
\hline Standard deviation & 0.0390 & 0.0327 & 9.0114 & 9395.93 & 1.7687 & 49.5119 & 0.1609 & 2438.6 \\
\hline Observations & 2454 & 2303 & 2451 & 2425 & 2456 & 2456 & 2433 & 2114 \\
\hline \multicolumn{9}{|l|}{ Correlations } \\
\hline Gini & 1.0000 & & & & & & & \\
\hline ri & -0.7333 & 1.0000 & & & & & & \\
\hline iia & 0.0662 & -0.0414 & 1.0000 & & & & & \\
\hline iiu & 0.2164 & -0.1616 & 0.3941 & 1.0000 & & & & \\
\hline edu & 0.1178 & -0.0003 & 0.03179 & 0.5208 & 1.0000 & & & \\
\hline pibpr10 & 0.0058 & 0.0112 & 0.3244 & 0.1911 & 0.2851 & 1.0000 & & \\
\hline idel & 0.1469 & -0.0955 & -0.1532 & -0.1836 & -0.2383 & -0.1267 & 1.0000 & \\
\hline gpubp & -0.1128 & 0.1441 & 0.0639 & -0.1802 & -0.1337 & 0.1777 & -0.0858 & 1.0000 \\
\hline
\end{tabular}

Source: Made by authors based on obtained data (see: Table 1).

acceptable results were not obtained in any of the cases and these weren't included in Table 3. Real municipal GDP per capita and its squared version, the ethno-linguistic fractionalization rate, per capita public expenditure and the householders' average years of education were used as control variables.

Table 3 presents the estimations' results:

The four equations presented in Table 3 have statistic significance as a whole. While the R squared adjusted looks low, this is common when working with cross-sectional estimates, whereas [45] mentions, levels close to 0.10 will be obtained generally, and levels higher than 0.2 would be exceptional. All cases presented the heteroskedasticity problem, so the equations were estimated under White and Huber/White's correction, coefficients and standard errors in Table 3 are the ones resulting from this adjustment. Variance inflation factors were also calculated, in all cases resulted lower than 5 and in most of them lower than 2, with this, and given the low correlation coefficients displayed in Table 2, among the explicative variables, the possible presence of the multicolinearity problem was discarded. It is also useful to mention that variance inflation factors in the independents that are included both in levels as in squared, were high. Their relation is not lineal, but quadratic, so it wasn't considered as a violation of the assumptions of the OLS method.

The most similar specification to the commonly estimated in literature on the study subject, is the one corresponding to Equation (1), for which the results of both the lineal coefficient as well as the quadratic of the financial inclusion variable, show the expected signs, according to [1] theory and are statistically different than 0 on a 99 per cent and 90 per cent confidence levels, respectively. In this same equation, the control variables' coefficients showed diverse results. The GDP (pibpr10) and GDP squared (pibpr10²) coefficient display the expected signs according to [3] theory, but weren't statistically different than 0. Finally, ethno-linguistic diversity (idel), per capita public expenditure (gpubp) and education level (edu), showed statistically significant coefficients. More diversity equals more inequality; the same happens with the low average municipal education levels. On the other hand, the increase of public expenditure per capita would lead to lower inequality levels, and this result confirms, at a regional level, the study made by [15]. 
Table 3. Estimated equations.

\begin{tabular}{|c|c|c|c|c|}
\hline \multicolumn{5}{|c|}{ Equations } \\
\hline & (1) & (2) & (3) & (4) \\
\hline Dependent variable & Gini & Gini & ri & ri \\
\hline Constant & $\begin{array}{l}0.3881^{* * *} \\
(0.00343)\end{array}$ & $\begin{array}{l}0.3928^{* * *} \\
(0.0042)\end{array}$ & $\begin{array}{l}0.1245^{* * *} \\
(0.0035)\end{array}$ & $\begin{array}{l}0.1205^{* * *} \\
(0.0036)\end{array}$ \\
\hline iia & $\begin{array}{l}0.0013^{* * * *} \\
(0.0004)\end{array}$ & & $\begin{array}{l}-0.0015^{* * *} \\
(0.0003)\end{array}$ & \\
\hline $\mathrm{iia}^{2}$ & $\begin{array}{l}-3.34 \mathrm{E}-5^{*} \\
(1.77 \mathrm{E}-5)\end{array}$ & & $\begin{array}{l}4.51 \mathrm{E}-5^{* * *} \\
(1.15 \mathrm{E}-5)\end{array}$ & \\
\hline iiu & & $\begin{array}{c}1.76 \mathrm{E}-6^{* * *} \\
(2.3 \mathrm{E}-7)\end{array}$ & & $\begin{array}{r}-1.36 \mathrm{E}-6^{* * *} \\
(1.6 \mathrm{E}-7)\end{array}$ \\
\hline $\mathrm{iiu}^{2}$ & & $\begin{array}{c}-2.92 \mathrm{E}-11^{* * * *} \\
(6.26 \mathrm{E}-12)\end{array}$ & & $\begin{array}{l}2.18 \mathrm{E}-11^{* * * *} \\
(4.53 \mathrm{E}-12)\end{array}$ \\
\hline pibpr10 & $\begin{array}{c}3.38 \mathrm{E}-5 \\
(3.23 \mathrm{E}-5)\end{array}$ & $\begin{array}{c}2.25 \mathrm{E}-5 \\
(3.17 \mathrm{E}-5)\end{array}$ & $\begin{array}{c}-1.07 \mathrm{E}-5 \\
(2.5 \mathrm{E}-5)\end{array}$ & $\begin{array}{l}-1.06 \mathrm{E}-5 \\
(2.53 \mathrm{E}-5)\end{array}$ \\
\hline pibpr10 $0^{2}$ & $\begin{array}{l}-4.53 \mathrm{E}-8 \\
(2.75 \mathrm{E}-8)\end{array}$ & $\begin{array}{l}-4.05 \mathrm{E}-8 \\
(2.56 \mathrm{E}-8)\end{array}$ & $\begin{array}{l}7.65 \mathrm{E}-9 \\
(2.05 \mathrm{E}-8)\end{array}$ & $\begin{array}{c}1.35 \mathrm{E}-8 \\
(1.98 \mathrm{E}-8)\end{array}$ \\
\hline idel & $\begin{array}{l}0.0438^{* * * *} \\
(0.0062)\end{array}$ & $\begin{array}{l}0.0466^{* * * *} \\
(0.0061)\end{array}$ & $\begin{array}{l}-0.0203^{* * * *} \\
(0.0053)\end{array}$ & $\begin{array}{c}-0.0218^{* * * *} \\
(0.0052)\end{array}$ \\
\hline gpubp & $\begin{array}{c}-1.50 \mathrm{E}-6^{* * *} \\
(5.46 \mathrm{E}-7)\end{array}$ & $\begin{array}{l}-8.83 \mathrm{E}-7^{*} \\
(5.34 \mathrm{E}-7)\end{array}$ & $\begin{array}{l}1.79 \mathrm{E}-6^{* * *} \\
(3.48 \mathrm{E}-7)\end{array}$ & $\begin{array}{l}1.34 \mathrm{E}-6^{* * *} \\
(3.53 \mathrm{E}-7)\end{array}$ \\
\hline edu & $\begin{array}{l}0.0036^{* * *} \\
(0.0005)\end{array}$ & $\begin{array}{l}0.0017^{* * *} \\
(0.0006)\end{array}$ & $\begin{array}{c}0.0006 \\
(0.0005)\end{array}$ & $\begin{array}{l}0.0021^{* * *} \\
(0.0005)\end{array}$ \\
\hline$R_{a j}^{2}$ & 0.07 & 0.10 & 0.04 & 0.06 \\
\hline Observations & 2085 & 2065 & 1981 & 1961 \\
\hline
\end{tabular}

Source: Made by the authors. ${ }^{* * *},{ }^{*}$ : Significant at $\alpha=0.01$ and 0.10 . Standard errors in parenthesis.

In Equation (2), when testing with a different financial inclusion indicator, in this case, usage index, results are consistent with Equation (1) and as this index grows, first it causes inequality, but then, in higher levels, equality.

When measuring inequality regarding income ratio (ri), Equations (3) and (4) show significant results that prove [1] theory. In this case, the signs for the financial inclusion variable are positive and negative respectively for the lineal and quadratic terms, which would be expected according with the theory, considering that this variable represents more equality when it grows, and less when it reduces its level, which is contrary to what happens to the Gini coefficient. The signs of the control variable coefficients and their significance are very similar to those of Equation (1). With the intention of avoiding a problem with the potential statistical mediation between the financial inclusion variable (iia or iiu) and the per capita GDP, the four models were also estimated without considering the financial inclusion variables. The results in every case still show coefficients that are statistically equal to 0 for the per capita GDP variables.

Starting from equations from Table 3, their vertices were calculated in terms of the interest variable. Even if Equations (1) to (4) refer directly to the study phenomenon, their vertices differ slightly between them, in Equation (1) the vertex happens, where: Gini $=0.4009$; and iia $=19.58$ (average financial system access points, per 10,000 inhabitants). In Equation (2), when substituting the access index for the usage index, the vertex is located at Gini $=0.4193$, and iiu $=30,137$. In the way the financial system access rate is measured, it can reach a maximum of 80,000, which would happen when every 10,000 inhabitants owned the 8 types of accounts available in its structure.

Using Equations (3) and (4) to obtain the critical points, in Equation (3), on the vertex, $r i=0.1118$; and iia = 17.47, while in Equation (4), that employs the usage rate as a financial inclusion, $r i=0.1035$ and iiu $=31,193$.

Figure 2 summarizes the municipalities' groups based on their financial development stage and income equality, according to each of these ordered pairs, each vertex of the estimated functions.

As set forth in each panel of Figure 2, 4 municipal groups can be observed, same that correspond to the division 


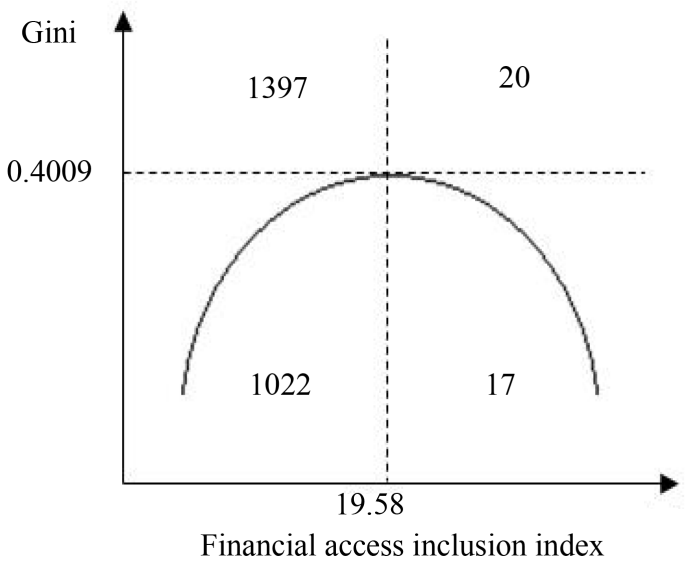

(a)

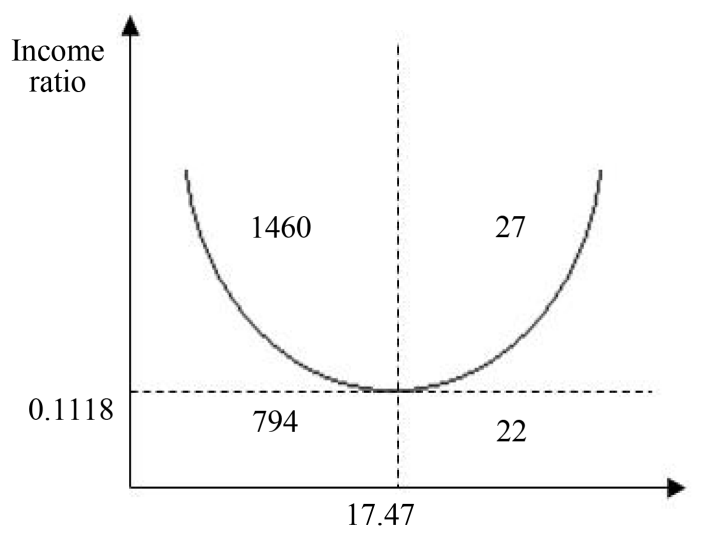

Financial access inclusion index

(c)

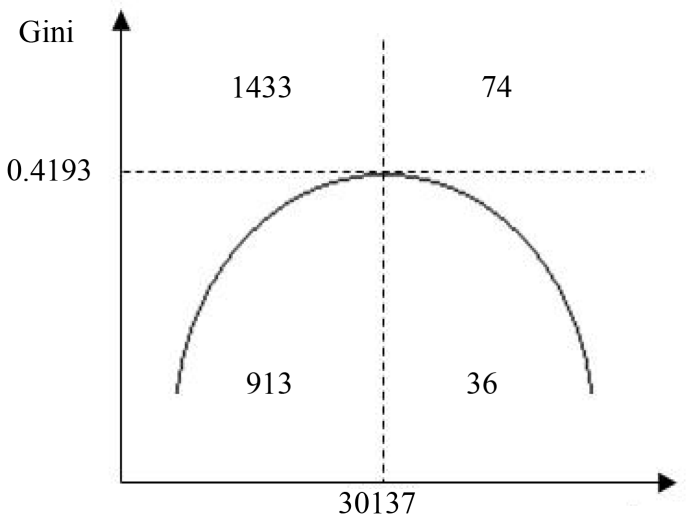

Financial usage inclusion index

(b)

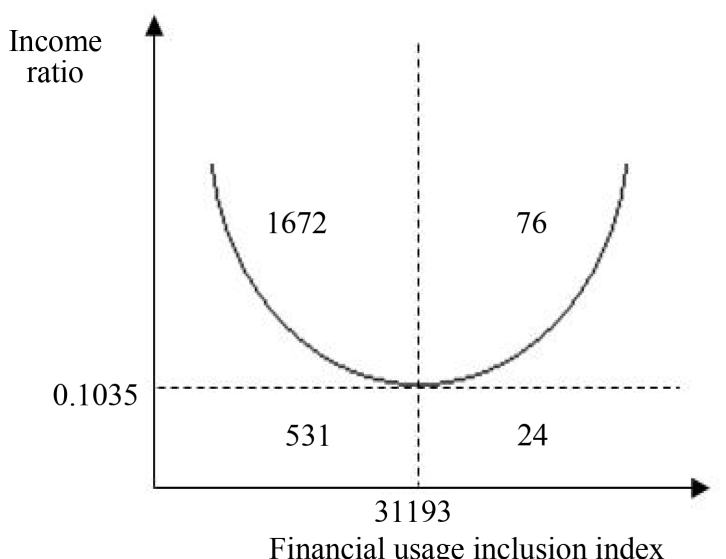

(d)

Figure 2. Mexicanmunicipalities’ distribution based on their financial development and income equality in 2010.

resulting from its coordinates in the Cartesian plane, where quadrants II and III display the low financial development municipalities, which is considered as financial inclusion in this study. In each panel of Figure 2, quadrants I and IV contains the highest financial developed municipalities, particularly in panels "a" and "b", quadrant IV the mature ones in [1] perspective and in panels "c" and "d", quadrant I.

As it can be observed in the four panels in Figure 2, most Mexican municipalities are below the inclusion levels corresponding to the vertex. Those located in quadrant IV of panels "a" and "b", and in the quadrant I of panels "c" and "d", are considered to be in the most desirable situation. This figure allows locating each Mexican municipality on either of the development levels stated in theory ${ }^{1}$. In terms of the present study, it was considered that municipalities located in quadrants II and III are closer to what in theory would be considered the infant stage of financial development, where it just starts manifesting where it previously hasn't, in quadrant I of panels "a" and "b", or in quadrant IV of panels "c" and "d", would be located those municipalities that already manifest an important financial inclusion, but are still highly unequal regarding income distribution, and finally, in quadrant IV of panels "a" and "b" and quadrant I of panels "c" and "d", are located municipalities that already reached the maturity stage and that according to theory, would be expected to remain there.

An alternate municipality division, developed under [1] inclusion cycle perspective, could consist of making the infant group those municipalities where the financial access and usage indexes have been equal to zero. In the same fashion, those grouped in the intermediate stage would be those where at least one of the rates is posi-

${ }^{1}$ The complete list of all the municipalities, and its classification in terms of its financial development, will be available upon request with the authors. 
tive, but hasn't still reached the vertex or an inequality level below the one located at the vertex, and finally, the group of municipalities in the mature stage, which would remain exactly the same as the one exposed in the previous division, and would be constituted by municipalities with a high inclusion and low income inequality. Under this division, the number of municipalities in each group, according to Equations (1) to (4) and their vertices, are shown in Table 4.

Of the 231 municipalities in the infant stage, 206 are located in Oaxaca state and the rest are distributed among 9 states. 23 of the states don't have municipalities undergoing this condition. The population from these municipalities represented 0.5 per cent of the national population by 2010, and Oaxaca state alone was 11.81 per cent.

On the other side of the curve, following Equation (4) criterion, that could be said is the least restrictive, there are 76 municipalities in the mature stage, 13 of them can be considered rural municipalities, the state median is 1 and the maximum of 9, this last one corresponding to México state. 15.85 per cent of the Mexican population was located in this group by 2010. The state with the higher population proportion residing in mature-stage municipalities was Aguascalientes, with 68.02 per cent, followed by the state of Coahuila, with 57.75 per cent, in 6 states this percentage was zero.

Next we present the main conclusions for the present study.

\section{Conclusions}

Results contained in Equations (1) to (4) lead to reject the two null hypothesis of the present investigation and prove the theoretic expectancy of [1] model. They would also allow to reject [22] [23] theories, all of this for Mexican municipalities.

This investigation's results have implications over public policy. They confirm that the path that financial inclusion public strategy adopted in Mexico in 2009 is coherent with the intention of world agencies like AFI, which gathers leaders and experts in monetary policy worldwide and constitutes a factor that incentivizes a more equalitarian income distribution in the long term. It also emphasizes that monetary policy will have more direct effects when focusing on quadrant II and III municipalities on Figure 2, where inclusion has been lower and where most of Mexican municipalities are located, particularly the 231 municipalities that in the most strict criteria are still in the infant stage, showing null financial inclusion; neither access nor usage.

Authorities from the three government levels, as well as directives from financial institutions and civil social promotion organisms, must fight for specific mechanisms that allow for municipalities in quadrants II and III to be gradually included in the formal financial system and to access products and services designed according to the different economies' functioning, ways of saving, and risk exposure.

Results on Mexico's regional reality are consistent with those obtained in comparative studies for whole countries. They widen the evidence towards indicators for income distribution different than Gini, as in this case were income ratio and financial inclusion variables that not only reflect upon the usage of the system, but also its accessing possibilities.

For 3 of the 8 variables in the study there was information available on 100 per cent of the Mexican municipalities, for the rest, there were data between 80 and 85 per cent of these. This is a limitation that could be reduced in future studies. Considering per capita public social expenditure as a control variable, more than the per

Table 4. Number of Mexican municipalities, according its financial development stage.

\begin{tabular}{ccccc}
\hline \multirow{2}{*}{$\begin{array}{c}\text { (Equation, panel): } \\
\text { Variables }\end{array}$} & Infant & Financial development stage & Mature & Total \\
\cline { 2 - 5 } (1, a): Gini and iia & 231 & 2208 & 17 & 2456 \\
(2, b): Gini and iiu & 231 & 2189 & 36 & 24 \\
(3, c): ri and iia & 231 & 2045 & 76 & 2303 \\
(4, d): ri and iiu & 231 & 1996 & 15.85 & 2303 \\
$\begin{array}{c}\text { Residing population as a percentage of } \\
\text { the national. (Using eq. 4, panel d) }\end{array}$ & 0.49 & 83.66 & & \\
\hline
\end{tabular}

Source: Made by the authors, based in estimated equations and its critical points. 
capita public expenditure, remains as a possibility for following studies, since it would be more directly linked to the objective of reducing inequality. Not counting on information on this subject was also a limitation for the present investigation.

Municipality groups in each of the quadrants of Figure 2 and/or Table 4, might be study cases on their own and differentiated groups could be distinguished even more precisely.

The present was a cross-section study with data for the 2010 year. The consideration of studies based on panel-data would allow to develop wider analyses, that help comparing groups through time or applying causality tests for phenomena that are still not clear theoretically, like the effects of financial inclusion on social cohesion, where the causality direction might be inverse to the considered in the present investigation, because, following [1] logic, the forming of social groups leads to the creation of wealth, better organization, creation of united work and efforts, and therefore, the development of an inclusive financial system.

Based on the present investigation's findings, one must bring to light [46] expression: "exclusion of the equalitarian inclusion" (p. 19), in which, Amartya Sen, the winner of the 1998 Nobel Prize of Economics, refers to the pitiful state of inequality inside large social groups worldwide, where social exclusion reigns, and particularly, the exclusion of equalitarian inclusion. Regarding financial inclusion, access and usage conditions must follow preferential schemes for vulnerable groups; the challenge is not only to make them geographically closer to financial services or just registering an account for them, but to build services ad hoc to their life conditions. The real concern must be reaching an equalitarian inclusion, more than just inclusion per se.

As [47] indicates, to identify the financial development stage of a country as a whole and of its separate regions, would allow for better monetary policies and mainly for specific programs created for making the financial system access and usage conditions more equal. In this sense, the present study groups the municipalities according to their financial development and with it offers elements that allow bettering focusing the public policies efforts and growth of the formal financial sector. It also considers that the efficacy of such efforts would be lessened if products and services are not created in response to the possibilities of the newcomers in the financial sector, if not, the inclusion effort might have a similar result to what happens in the story titled "Canastitas en serie" (Roughly, "Little serial handmade baskets") by [48], where Mr. E. L. Winthrop couldn’t make a life’s business when a humble Mexican peasant explained to him that the more hand-woven baskets he ordered producing, the higher its unitary price. This was common sense to the peasant, but incomprehensible for Mr. Winthrop, a New York businessman more used to serial production ways.

\section{Acknowledgements}

To UJAT for their support to Bethzaira to participate in the scientific summer 2015 program. To the September workshop participants at Tecnologico de Monterrey, Economics Department. To José Salazar Pozos, for his help in the translation of the base document

\section{References}

[1] Greenwood, J. and Jovanovic, B. (1990) Financial Development, Growth, and the Distribution of Income. Journal of Political Economy, 98, 1076-1107. http://dx.doi:10.1016/0165-1889(95)00928-0

[2] Piketty, T. (2014) El capital en el siglo XXI. Fondo de Cultura Económica, México.

[3] Kuznets, S. (1955) Economic Growth and Income Inequality. The American Economic Review, 45, 1-28.

[4] Tan, H. and Law, S. (2012) Nonlinear Dynamics of the Finance-Inequality Nexus in Developing Countries. Journal of Economic Inequality, 10, 551-563. http://dx.doi:10.1007/s10888-011-9174-3

[5] Tapia, T. (2015) La desigualdad: Problema grave, desafío exigente. Adgentes, 68, 28-31.

[6] Instituto Nacional de Estadística y Geografía (2010) Censo de población y vivienda 2010. INEGI, Aguascalientes. http://www3.inegi.org.mx/sistemas/tabuladosbasicos/default.aspx?c=27302\&s=est

[7] Layard, R. (2005) La felicidad. Taurus, México.

[8] Espinosa, A., Hernández, J., Leal, R. and Ramos, G. (2009) Las determinantes del crimen en Mexico. Revista Estudiantil de Economía, 1, 1-20.

[9] Tello, C. (2009) Sobre la desigualdad en México. UNAM, México.

[10] Hernández, E. and Córdova, J. (1979) Estructura de la distribución del ingreso en México. Comercio Exterior, 29, 505520 . 
[11] World Bank (2015) 2015 World Bank Indicators. http://data.worldbank.org/indicator

[12] UNU-WIDER (2014) UNU-WIDER World Income Inequality Database, Version 3.0B, September 2014. UNUWIDER, Helsinki. http://www.wider.unu.edu/research/WIID3-0B/en_GB/wiip

[13] Peña, X., Hoyo, C. and Tuesta, D. (2014) Determinantes de la inclusión financiera en México a partir de la ENIF 2012. BBVA Research: Documento de trabajo, No. 14/14. https://www.bbvaresearch.com/wp-content/uploads/2014/06/WP_1414.pdf

[14] Roa, M. (2015) Financial Inclusion in Latin America and the Caribbean: Access, Usage and Quality. Documentos de Investigación del Centro de Estudios Monetarios Latinoamericanos 19. http://www.cemla.org/PDF/investigacion/inv-2015-04-19.pdf

[15] Secretaría de Hacienda y Crédito Público (2015) Distribución del pago de impuestos y recepción del gasto público por deciles de hogares y personas. Resultados para el año de 2012. Secretaría de Hacienda y Crédito Público. http://www.shcp.gob.mx/INGRESOS/ingresos_distribucion_pago/doc_Ingreso-Gasto_2012_enero2015.pdf

[16] García-Herrero, A. and Martínez-Turégano, D. (2015) Financial Inclusion, rather than Size, Is the Key to Tackling Income Inequality. BBVA Research. Working Paper 15/05. https://www.bbvaresearch.com/wp-content/uploads/2015/02/WP_Financial-Inclusion-Income-Inequality4.pdf

[17] Peña, E. (2013) Plan Nacional de Desarrollo 2013-2018. Presidencia de México. http://pnd.gob.mx/

[18] Diario Oficial de la Federación (2011) Acuerdo por el que se crea el Consejo Nacional de Inclusión Financiera. http://dof.gob.mx/nota detalle.php?codigo=5212351\&fecha=03/10/2011

[19] Banco de Mexico (2011) Circular 14/2011. Banco de Mexico. http://www.banxico.org.mx/disposiciones/circulares/\%7BC2700F0B-A5BA-3585-7CBB-35E0CAEDA9B2\%7D.pdf

[20] Alonso, J., Fernández de Lis, S., Hoyo, C., López-Moctezuma, C. and Tuesta, D. (2013) La banca móvil en Mexico como mecanismo de inclusión financiera: Desarrollos recientes y aproximación al mercado potencial. BBVA Research. Working Paper 13/19. https://www.bbvaresearch.com/KETD/fbin/mult/WP_1319_Mexico_BancaMovil_tcm346-390713.pdf

[21] Consejo Nacional de Inclusión Financiera (2015) ¿Qué es la inclusión financiera? CONAIF. http://www.cnbv.gob.mx/Inclusi per centC3 per centB3n/Paginas/Descripci per centC3 per centB3n.aspx

[22] Banerjee, A. and Newman, A. (1993) Occupational Choice and the Process of Development. Journal of Political Economy, 101, 274-298. http://dx.doi.org/10.1086/261876

[23] Matsuyama, K. (2000) Endogenous Inequality. The Review of Economic Studies, 67, 743-759. http://dx.doi.org/10.1111/1467-937X.00152

[24] Olvera, G., Collado, N., Martínez, A. and Bueno, M. (2014) Diversidad poblacional y crecimiento económico en Mexico. Revista Estudiantil de Economía, 6, 1-20.

[25] Liu, Z. and Wang, Q. (2015) Is There a Reverse U-Shaped Relation between Financial Development and Income Distribution? Comparison between Developed Countries and Transforming Countries. Open Journal of Social Sciences, 3, 201-209. http://dx.doi.org/10.4236/jss.2015.33030

[26] Dabla-Norris, E., Ji, Y., Townsend, R. and Filiz, D. (2015) Distinguishing Constraints on Financial Inclusion and Their Impact on GDP and Inequality. NBER Working Paper No. 20821. http://www.nber.org/papers/w20821

[27] Beck, T., Demirguc-Kunt, A. and Martinez, M. (2007) Reaching out: Access to and Use of Banking Services across Countries. Journal of Financial Economics, 85, 234-266. http://dx.doi.org/10.1016/j.jfineco.2006.07.002

[28] Honohan, P. (2006) Household Financial Assets in the Process of Development. World Bank Policy Research, wp. 3965. http://documents.worldbank.org/curated/en/docsearch/document-type/620265 http://dx.doi.org/10.1596/1813-9450-3965

[29] Honohan, P. (2007) Cross-Country Variation in Household Access to Financial Services. World Bank Conference on Access to Finance, Washington DC, 15-16 March 2007. World Bank, Trinity College Dublin and Centre for Economic Policy Research.

http://siteresources.worldbank.org/INTFR/Resources/Cross_Country_Variation_In_Household_Access.pdf

[30] Clarke, G., Xu, L. and Zou, H. (2006) Finance and Income Inequality: What Do the Data Tell Us? Southern Economic Journal, 72, 578-593. http://www.jstor.org/stable/20111834 http://dx.doi.org/10.2307/20111834

[31] Rioja, F. and Valev, N. (2004) Finance and the Sources of Growth at Various Stages of Economic Development. Economic Inquiry, 42, 127-140. http://dx.doi.org/10.1093/ei/cbh049

[32] Cámara, N. and Tuesta, D. (2014) La banca del futuro, la banca de todos: El Modelo Perú. BBVA Research, Observatorio Inclusión Financiera, 1-6. https://www.bbvaresearch.com/wp-content/uploads/2014/09/observatorio-peru-inclusion-maq1.pdf 
[33] Peña, P. and Vázquez, A. (2012) El impacto de los corresponsales bancarios en la inclusión financiera: Una primera evaluación. Estudios Económicos CNBV, 1, 195-215.

http://www.cnbv.gob.mx/CNBV/Estudios-de-la-CNBV/Estudios\%20de\%20investigacion/Impacto_Corresponsales_Ba ncarios.pdf

[34] Mbutor, M. and Uba, I. (2013) The Impact of Financial Inclusion on Monetary Policy in Nigeria. Journal of Economics and International Finance, 5, 318-326. http://dx.doi.org/10.5897/JEIF2013.0541

[35] Kempson, E., Whyley, C., Caskey, J. and Collard, S. (2000) In or Out? Financial Exclusion: A Literature and Research Review. Financial Services Autority, Bristol.

[36] Ghosh, M. and Ghosh, A. (2014) Financial Inclusion Strategies of Banks: Study of Indian States. International Journal of Applied Financial Management Perspectives, 3, 990-995. https://www.researchgate.net/profile/Munmun_Ghosh2/publication/268852965_FINANCIAL_INCLUSION_STRATE GIES_OF_BANKS_STUDY_OF_INDIAN_STATES/links/54798c2f0cf293e2da2b4267.pdf

[37] Preciado, C. and Díaz, C. (2013) Nivel de inclusión financiera y barreras de acceso de la población adulta de la C. de Autlán de Navarro, Jalisco. Global Conference on Business and Finance Proceedings, 8, 738-750. http://www.theibfr.com/ARCHIVE/ISSN-1941-9589-V8-N2-2013.pdf

[38] Trevinyo-Rodíguez, L. and Chamiec-Case, L. (2012) Pursuing Financial Inclusion of Family Firms at the Base of the Pyramid (BoP): The Case of Convenience Stores and Microenterprises in Nuevo León, Mexico. Journal of Small Business and Entrepreneurship, 25, 231-248. http://dx.doi.org/10.1080/08276331.2012.10593571

[39] Shafi, M. and Hawi, A. (2012) Financial Inclusion in Developing Countries: Evidences from an Indian State. International Business Research, 5, 116-122. http://dx.doi.org/10.5539/ibr.v5n8p116

[40] Makesh, K.G. and Kuzhuvelil, M. (2014) Financial Inclusion: A Literature on Its Causes and Effects. International Journal of Applied Financial Management Perspectives, 3, 745-750.

[41] Jiménez, C. (2015) La virtud de la neblina, interculturalidades posibles en Mexico. Este País, Tendencias y Opiniones, 3, 5-7.

[42] Baldomero, L., Husemann, W., González, D. and Ramos, A. (2012) Efectos diferenciados de la política monetaria en Mexico: El caso de las entidades federativas a nivel nacional. Gaceta de Economía, 18, 43-73.

[43] Kliksberg, B. (2009) ¿Qué significa vivir en América Latina la región más desigual de todas? El caso de la salud pública. In Sen, A. and Kliksberg, B., Eds., Primero la gente: Una mirada desde la ética del desarrollo a los principales problemas del mundo globalizado, Temas, Buenos Aires, 111-177.

[44] De León, J., Dorta, J. and Pérez, J. (2010) Contraste de los modelos de asignación presupuestaria en el presupuesto social municipal. Gestión y Política Pública, 19, 351-394.

http://www.gestionypoliticapublica.cide.edu/num_anteriores/Vol.XIX_No.II_2dosem/05_De_Leon_Ledezma-Jose_An dres Dorta.pdf

[45] Greene, W. (2008) Econometric Analysis. Pearson Prentice Hall, Upper Saddle River.

[46] Sen, A. (2009) Exclusión e inclusión. In Sen, A. and Kliksberg, B., Eds., Primero la gente: Una mirada desde la ética del desarrollo a los principales problemas del mundo globalizado, Temas, Buenos Aires, 17-32.

[47] Roa, M. (2014) La inclusión y la estabilidad financieras. Documentos de Investigación del Centro de Estudios Monetarios Latinoamericanos. http://www.cemla.org/PDF/investigacion/inv-2013-12-15.pdf

[48] Traven, B. (2003, [1956]) Canasta de cuentos mexicanos. Selector, México.

[49] Ibarra-Salazar, J. and Varella-Mollick, A. (2006) Mexican Northern Border Municipalities, Financial Dependence and Institutions. Annals of Regional Science, 40, 859-874. http://dx.doi.org/10.1007/s00168-005-0036-4 